\title{
Analysis of The Implementation of Online Referral for National Health Security Participant at PKU Muhammadiyah Karanganyar Hospital
}

\author{
Iik Sartika ${ }^{1 *}$, Ahyar Mahasin ${ }^{2}$ \\ Faculty of Public Health, Veterans Bangun Nusantara Sukoharjo University \\ * iiksartika.8@gmail.com
}

\begin{abstract}
National Health Insurance is part of the National Social Security System organized by the Health Social Security Administering Agency through a mandatory social health insurance mechanism based on Law No. 40 of 2004 concerning the National Social Security System. Improving the quality of BPJS services with a referral system. Online referral is a digitalization of a tiered referral process for the ease and certainty of participants in obtaining services in hospitals tailored to the competence, distance and capacity of the referral destination hospital based on the patient's medical needs. Implementation of the National Health Insurance Policy on leads online in Hospital of PKU Muhammadiyah Karanganyar, found a problem of applying a referral system based on "Permenkes" number 01 of 2012 with the referral system SOP at PKU Muhammadiyah Karanganyar Hospital.

This research is kualitatif with the approach of case studies. This research was conducted in April-August 2019 at PKU Muhammadiyah Karanganyar Hospital. Research methods with in- depth interviews and observations related to implementation, obstacles, supporting factors, and policies related to online referrals.

The results of the study showed the compatibility between the results of the implementation in the field compared with existing regulations. Implementation has met the needs of human resources and infrastructure, the flow stage is in accordance with Permenkes number 01 of 2012, obstacles that arise due to the delegation of focused authority, supporting factors, namely good coordination between units, and policies on SOP regarding full referral which do not regulate in detail about implementing online referrals. Recommendations based on this research, it is hoped that an evaluation of the implementation of the National Health Insurance policy on online referrals at PKU Muhammadiyah Karanganyar Hospital and improve services will be better.
\end{abstract}

Keywords: National Health Insurance, Hospital, Online Referral 


\section{STRADA Jurnal Ilmiah Kesehatan}

DOI: $10.30994 /$ sjik.v9i1.323

ISSN: 2252-3847 (print); 2614-350X (online)

Vol.9 No.1. May 2020. Page.286-296

\section{INTRODUCTION}

Health service referral system is the organization of health services that regulates the transfer of tasks and reSOPnsibilities of health services vertically or horizontally. Horizontal referral is a referral between health services at one level, and vertical referrals are referrals made from lower service levels to higher service levels or vice versa. The referral system is carried out in stages starting from the first level health services and advanced referral health services consisting of second level health services (specialist) and third level health services (subspecialistic).

The social security administering body will not use health care facilities in the health care system if the health care facilities do not implement a referral system. The high referral ratio caused by the implementation of referrals that are not in accordance with the level of the level will cause the accumulation of patients in one of the health care providers, which in turn will have an impact on the quality of service. It can also be detrimental financially and affect the achievement of performance in the health sector. The impact received by "BPJS" of Health if primary health facilities refer patients excessively and disproportionately, that is, "BPJS" of Health will be harmed by paying referral cases in secondary and tertiary health care facilities that actually should not be referred to the capitation payment system at the first level health facility (Manulang, 2008).

In an effort to achieve increased participant satisfaction, "BPJS" of health implements a tiered referral system by launching an online referral system. Online referrals make it easy for health facilities to refer because FKTP is able to find out poly at the Advanced Referral Health Facility and its practice schedule, making it easier for patients to obtain health services.

Based on the Minister of Health Regulation number 01 of 2012 concerning Individual Health Services Referral System, individual health services consist of 3 (three) levels including: (1) First level health services, constituting basic health services, (2) Second level health services constituting health services specialties performed by specialist doctors or dental specialists, (3) Third-level health services are sub-specialty health services performed by sub-specialist doctors or sub-specialist dentists.

Health services at the first level and advanced level of health facilities must carry out a referral system with reference to the applicable laws and regulations. Participants who want to get services that are not in accordance with the referral system can be included in the service category that is not in accordance with the procedure so that it cannot be paid by "BPJS" of Health.

Health facilities that do not implement a referral system will "BPJS" of Health will do a recredentialing (re-evaluation) of the performance of the health facility and can have an impact on the continuation of cooperation. Referral services can be carried out horizontally or vertically. Horizontal referral is a referral made between health services in one level if the referral cannot provide health services according to the needs of the patient due to limited facilities, equipment and personnel that are temporary or permanent.

The online referral system is a digitalization of a tiered referral process for the ease and certainty of participants in obtaining services in hospitals tailored to the competency, distance and capacity of the referral destination hospital based on the patient's medical needs. Stages of the online referral system include: (1) Phase 1 of the period 15-31 August 2018, in this phase 


\section{STRADA Jurnal Ilmiah Kesehatan}

DOI: $10.30994 /$ sjik.v9i1.323

ISSN: 2252-3847 (print); 2614-350X (online)

Vol.9 No.1. May 2020. Page.286-296

"FKTP" used the Pcare application to refer and the Hospital still received manual referrals. (2) Phase 2 of the period 01-15 September 2018, in this phase "FKTP" is required to use the Pcare application to refer, except for "FKTP" who have not been connected to a data communication network or the internet. Hospitals only accept online referrals . (3) Phase 3 period 16-30 September 2018, in this phase "FKTP" is required to use the Pcare application to refer to consideration of the capacity and distance of the intended "FKRTL". Hospitals only accept online referrals .

PKU Muhammadiyah Karanganyar Hospital is a type C hospital in Karanganyar Regency, with a plenary accredited Hospital Accreditation Commission (KARS). PKU Muhammadiyah Karanganyar Hospital has 12 specialist polyclinic services with 23 specialist doctors. PKU Muhammadiyah Karanganyar Hospital in collaboration with BPJS since 2014, the hospital in collaboration with BPJS implemented an online referral. The flow of an online referral system at PKU Muhammadiyah Karanganyar Hospital is a patient after conducting an examination with a specialist doctor to the registration section to print the Participant Eligibility Letter (SEP) to the hospital and the intended clinic, then the patient or family goes to the Polyclinic for the nurse's signature. The online referral applies if there is already a written referral from a specialist and SEP between hospitals.

Based on preliminary studies at PKU Muhammadiyah Karanganyar Hospital, Jalan Papahan Tasikmadu-Karang Anyar, Central Java, it shows that Health Facilities 1 (Puskesmas) can only refer to hospitals type $\mathrm{C}$ and D, so that the accumulation of patients is in that type of hospital. (2) To refer to class $\mathrm{C}$ and $\mathrm{D}$ types based on the mapping process in the BPJS online referral system, so patients cannot be served online referrals outside the area specified by the BPJS online referral system. The increase in the number of patients is $13 \%$ from before the online referral was implemented, namely in phase 3 of the period 16-30 September 2018, in this phase "FKTP' was required to use the Pcare application to refer to consideration of the capacity and distance of the intended "FKRTL". Hospitals only accept online referrals. The online referral system influences the number of outpatient visits at PKU Muhammadiyah Karanganyar Hospital . Based on the background description above, the researchers formulated the problem, including knowing the preparation of the implementation of the National Health Insurance (JKN) policy on online referral at PKU Muhammadiyah Karanganyar Hospital, the flow of implementation, obstacles, supporting factors, and online referral system policies .

\section{METHODS}

Design reseach is qualitative case study approach in PKU Muhammadiyah Hospital in Karanganyar. Qualitative approach is very easy to use in health management (Cresswell, 2014). The study was conducted at PKU Muhammadiyah Karanganyar Hospital in April - June 2019. Research methods with in-depth interviews and observations related to implementation, obstacles, supporting factors, and policies related to online referrals. The informants in this study were the Head of Services and medical record staff at PKU Muhammadiyah Karanganyar Hospital. The instruments used were in-depth interview guidelines which were adjusted to Permenkes Number 1 of 2012 and hospital-related Standard 
STRADA Jurnal Ilmiah Kesehatan

DOI: $\underline{10.30994 / \text { sjik.v9i1.323 }}$

ISSN: 2252-3847 (print); 2614-350X (online)

Vol.9 No.1. May 2020. Page.286-296

Operating Procedures (SOPs) for online referrals . This study will provide an overview of the implementation of online referrals in hospitals based on existing policies and reality in the field.

\section{RESULTS}

\section{Implementation of Online Referral System}

In the preparation stage for online referral implementation at PKU Muhammadiyah Karanganyar Hospital, it was obtained from indept interviews (in-depth interviews) sourced from interview guidelines as follows: reSOPndents or outpatient polyclinic employees who carry out or have a role in making referrals, there are 4 registration officers and polyclinic nurses there are 15 people.

" There are 15 nurses in the polyclinic here and 4 in the registration, with limited officers it is hoped that officers can work as much as possible with 13 specialist polyclinics with 25 specialist doctors." (Chief of Polyclinic). "

Based on the results of interviews with the Head of Polyclinic Services, there were 4 polyclinic registration staff and were reSOPnsible for the online referral system. All reSOPndents or policlinic officers at PKU Muhammadiyah Karanganyar Hospital stated that they had carried out referrals in accordance with the Standard Operating Procedure (SOP) on referrals. PKU Muhammadiyah Hospital in Karanganyar not display specialist at Polyclinic schedule, but the patient has already been socialized by a security guard or officer can contact the customer service u ntuk schedule for specialists. PKU Muhammadiyah Karanganyar Hospital as a level 2 health facility received a referral from health facility 1 in the Karanganyar Regency. The number of health facilities 1 in Karanganyar Regency is 71, not including practicing dentists in collaboration with BPJS, including: (1) General practitioners totaling 26, (2) Puskesmas totaling 21, (3) Clinics totaling 24, and (4) there are 4 hospitals type C and type D, which are: hospital of PKU Muhammadiyah Karanganyar type C, Regional General hospital Karanganyar type C, hospital Dian Pertiwi Karanganyar type D, and hospital Husada Karanganyar D type .

Establishing health facility 2 hospital as a referral based on the zoning system in the referral system program at level 1 health facilities. Patients receive referrals to hospitals with specialist poly goals accompanied by a kujungan plan and a doctor's practice schedule valid for 3 months from making the referral. Online referral system makes it easy for patients to get doctor information at the destination hospital. Questions on facilities and infrastructure, all respondents answered that facilities and infrastructure in the polyclinic were sufficient to create an online referral system. Infrastructure facilities in the form of staff and supporting services in the form of computers, loudspeakers, TV patient queues, internet networks, and printers.

The flow of the implementation of online referrals is a sequence of events that are mutually sustainable and produce results in the form of online referral letters. The flow of implementation based on indept interviews is sourced from interview guidelines and direct observation in the service of the clinic, especially the implementation of online referrals in the clinic. Implementation of online referrals that respondents have carried out tasks in accordance with their respective jobdesk.

" BPJS patients after registering a polyclinic by bringing a referral from health facility $I$, then waiting in the specialist waiting room at the polyclinic according to their purpose, if after 


\section{STRADA Jurnal Ilmiah Kesehatan}

DOI: $10.30994 /$ sjik.v9i1.323

ISSN: 2252-3847 (print); 2614-350X (online)

Vol.9 No.1. May 2020. Page.286-296

examination the doctor cannot handle or limited support at PKU Muhammadiyah Karanganyar Hospital, the specialist doctor will refer patients to the above type of hospital (vertical referral) or similar hospitals (horizontal referral) who have more complete support or specialist doctors who are more competent in their fields. " (Chief of Polyclinic). "

The registrar makes a Participant Eligibility Letter (SEP) based on the doctor's reference that has been made.

"The registration officer makes a referral according to a manual referral from a specialist doctor then the registration officer enters the patient's SEP number, the destination hospital, plans for examinations at the hospital to be addressed, and the destination polyclinic. For reference letters, valid for 3 months or 90 days after registration make the referral letter. " (Head of Registration Service) ".

After making the SEP in the patient registration to the clinic again to get approval from the polyclinic officer. Online referral aims to make it easier for patients to get specialist doctor's information, hours of polyclinic practice, and the number of patient quotas at the targeted polyclinic.

\section{Barriers to Implementation Online Referral}

The implementation of online referrals experiences obstacles obtained from in- depth interviews and direct observation in the clinic.

" Polyclinic registration officers are limited, especially afternoon attendants so that the making of referral SEPs has been delayed in their production which causes patients to have to wait for the referral SEPS. Not to mention the interruption of internet connection or simRS maintenance or from the BPJS "(Registration Officer)."

Also, there is no notice board for referral patient services, which raises questions for patients and their families. Polyclinic officers are given the authority of BPJS to give patient approval to be referred to type C, type B hospitals, or to referral hospitals (type A) depending on the patient's disease history. Giving authority is only given to one polycyclist or polyclinic head.

" Polyclinic officers who are given the authority to enter during working hours are from 07.00 to 14.00 and there are no hospitals. For online referral SEPs, they still have to wait for approval from the head of the polyclinic during these hours or can be taken the next day. " (Chief of Polyclinic).

Hambatan constraints in addition to the above there are also external barriers that the process of making a referral from a health facility SEP 1, which is one of the input or stored specialist referrals that result does not appear referral from a health facility 1 "BPJS" program at the hospital.

\section{Supporting Factors of Online Referral}

Supporting factors facilitate the implementation of online referrals in Muhammadiyah Karanganyar Hospital. Implementation is based on in- depth interview sources from interview guidelines. The registration officer can carry out outpatient services with several supporting factors to facilitate the service in the clinic.

" Supporting factors in polyclinic registration are smooth internet and other supporting tools such as computers, speakers, microphones, TV polyclinic queues, polyclinic queue devices and others. In our service coordination is also established between good registration units, 
STRADA Jurnal Ilmiah Kesehatan

DOI: $\underline{10.30994 / \text { sjik.v9i1.323 }}$

ISSN: 2252-3847 (print); 2614-350X (online)

Vol.9 No.1. May 2020. Page.286-296

polyclinics, and emergency rooms which are expected to put patients first who are in need of better and faster care. (Head of Registration). "

Polyclinic officers are also assisted by specialist doctors who practice in addition to the PKU Muhammadiyah Karanganyar Hospital making it easier for the referral process to other hospitals.

" Most specialist doctors at PKU Muhammadiyah Karanganyar Hospital work outside Karanganyar Regency, making it easier for the referral process from the polyclinic or emergency room. Doctors also understand more about subspecialists and in hospitals where patients should be referred. " (Chief of Polyclinic). "

Some of these supporting factors can improve the quality of health services to patients. Where the main goal in hospital accreditation is patient safety, so that in getting patient referrals more quickly handled by health facilities that are more complete supporting tools and specialist doctors.

\section{Online Referral Policy}

Referral Standard Operating Procedure (SOP) at PKU Muhammadiyah Karanganyar Hospital . Referral destinations include pime Frame system of referral performing well, and m enjadi material efficiency ratings for public financing of insured people or social health insurance. Patients who are referred must have been examined and are eligible to be referred by following the procedure for referring patients according to the attachment of the Decree of the Director of PKU Muhammadiyah Karanganyar Hospital No 090 / III.6.AU / RS / PKU / U / IV / 2016 regarding hospital service policy.

Table 1. Online Referral Procedure

\begin{tabular}{cl}
\hline No & Online referral procedure \\
\hline 1. & Criteria for patients referred, are: \\
a. The results of the physical examination can certainly not be overcome. \\
b. The result of physical examination with supporting medical examination was \\
not able to be overcome. \\
c. Requires a more complete medical support examination, but the examination \\
must be accompanied by the patient concerned. \\
d. If it has been treated and cared for, it requires examination, treatment, and \\
treatment of health facilities that are more capable. \\
Procedures refer patients \\
a. Perform anamnesa, physical examination and supporting examinations to \\
determine the main diagnosis and differential diagnosis. \\
b. Provide pre referral actions according to the case based on SOP. \\
c. Fill in the patient's medical record in accordance with the results of the \\
assessment carried out. \\
d. Decide on a referral and contact the referral hospital. \\
e. Give informed consent (approval or refusal of referrals). \\
f. Make a duplicate patient referral letter 2. \\
g. The patient's assistant is in accordance with the criteria of the patient \\
referred.
\end{tabular}

Website: $\underline{\text { https://sjik.org/index.php/sjik | Email: publikasistrada@gmail.com }}$ 


\section{STRADA Jurnal Ilmiah Kesehatan}

DOI: $10.30994 /$ sjik.v9i1.323

ISSN: 2252-3847 (print); 2614-350X (online)

h. The process of transferring patients to the referral destination hospital in accordance with the external transfer SOP.

i. The patient accompanying officer hands over the officer at the referral destination hospital.

j. Patient escort officers and ambulances wait for patients in the destination emergency room until there is certainty that the patient will receive services and conclusions of being hospitalized or outpatient.

PKU Muhammadiyah Karanganyar Hospital has a SOP about referrals, but the SOP has not explained specifically regarding online referrals .

\section{DISCUSSION}

The referral system in Indonesia has not been effective so it has an impact on the accumulation of patients in advanced health facilities, resulting in the use of skilled labor and sophisticated equipment that is not appropriate and decreasing the quality of health services. The implementation of JKN brought improvements in the referral system at the RSUD Dr. Adjidarmo Lebak Regency. The tiered referral system component requires new improvements to the aspects of policies and procedures, so that efforts are still needed to improve other aspects in order to create a better referral system.

\section{Implementation of Online Referral System}

Based on the results of the research "Implementation of the National Health Insurance Policy About Online Referral (Case Study at PKU Muhammadiyah Karanganyar Hospital)", for implementation based on Permenkes number 01 of 2012 concerning the referral system for individual health services. There is a similarity with the researcher entitled Analysis of the Implementation of a Tiered Referral System for JKN Participants in Surabaya City Health Center, which concludes that there is a similarity about the National Referral System in Permenkes number 01 of 2012 including the conditions for referring patients and procedures for referring patients.

Karleanne Lony Primasari's research on the Analysis of the National Health Insurance Referral System of RSUD. Dr. Adjidarmo Lebak Regency, the result of which is the National Health Insurance (JKN) is the implementation of Law Number 40 of 2004 concerning the National Social Security System (SJSN) in the field of health with the concept of Universal Health Coverage ( UHC) which forces participants to follow a tiered referral system to obtain health services. comprehensive, inexpensive, affordable, but quality.

The online referral preparation stage at PKU Muhammadiyah Karanganyar Hospital is described from the results of the answers in the interview guidelines that the online referral implementation is in accordance with Permenkes number 01 of 2012 where health services are carried out in stages according to medical needs starting from the first level of health services, second level health services only can be provided with referrals from first level health services, and third level health services can only be given on referrals from second level or first level health services. The preparation phase in the online referral at PKU Muhammadiyah 


\section{STRADA Jurnal Ilmiah Kesehatan}

DOI: $10.30994 /$ sjik.v9i1.323

Karanganyar Hospital includes: knowing HR (Human Resources), doctor's schedule, referral health facilities, and infrastructure.

As stated in the results that the reSOPndents stated that hospital polyclinic officers had implemented a referral system at PKU Muhammadiyah Karanganyar Hospital with the issuance of SOP about referrals with document number 22.PO.06. The SOP for the referral system does not regulate in detail the implementation of online referrals, where the SOP regulates referrals for emergency patients, for referral SOPs online polyclinic does not yet exist. The online polyclinic referral according to reSOPndents so far has been carried out according to the expected flow of hospital management by prioritizing ease in patient care.

PKU Muhammadiyah Karanganyar Hospital is a second level health care institution that receives referrals from first level health facilities. The implementation phase is in accordance with Permenkes number 01 of 2012 concerning the referral system, which runs a tiered referral system from the first, second, and third levels. Understanding of health workers regarding the referral flow is good. Referral flow has referred to the national provisions regarding tiered referral regulated in Permenkes number 01 of 2012 Article 4. Procedure flow in online referral services at PKU Muhammadiyah Karanganyar Hospital includes: (1) Patients submit queuing numbers and requirements to the clinic registration including a referral or control sheet, (2) The registration clerk checks the patient data in the BPJS vClaim system, if it still applies the patient is made an outpatient SEP and a doctor queue number, (3) Patients go to the clinic submit a registration file and blood pressure, then wait in the doctor's queue, (4) When the patient is examined if it cannot be served due to limited support, specialists, and diagnosis of certain patients, the patient has the right to be referred, (5) Patients to the registration for making a referral SEP carry a file from the clinic, and (6) After printing the SEP the patient's referral returns to the clinic for acc referral to the destination hospital (Hartini, 2016).

Implementation of referrals in hospitals there are inhibiting factors in the implementation of referrals where there is no referral system flow, but seeing the results of obervasi on patients have been educated by officers to go to the unit in the hospital, that is, after the patient gets a doctor's examination, the patient goes to the registration carrying a referral letter introduction specialist doctors for making online SEP referrals, after that the pasine goes to the polyclinic for approval of online referral SEP. The implementation process can be minimized by a better planning process. Planning emphasizes service quality in terms of place, time, and service flow. Planning activities will be the basis for the implementation of the next activity, namely implementation. The success or failure of implementation will greatly depend on the extent to which the quality of planning can be used as a strong and quality foothold for the implementation phase (Luti et al., 2012).

\section{Barriers to implementing Online Referrals}

Based on Karleanne Lony Primasari's research (2015), the obstacle in implementing a referral SOP is that communication does not run smoothly when referring patients, where not all cases to be referred are confirmed to go to the destination hospital, but in the JKN era with increasingly stringent JKN rules regarding the provisions referral indication.

According to reSOPndents related to the many obstacles due to the limited polyclinic officers both nurses and polyclinic registration officers are the main causes in the implementation of online referrals. In the morning shift nurses clinic there are 8 officers and in 


\section{STRADA Jurnal Ilmiah Kesehatan}

DOI: $10.30994 /$ sjik.v9i1.323

ISSN: 2252-3847 (print); 2614-350X (online)

Vol.9 No.1. May 2020. Page.286-296

the afternoon there are 7 officers, for the polyclinic registration there are 4 officers in the morning and 1 person in the afternoon shift. Officers who are limited by the number of specialist doctors are expected to be able to maximize the work in each unit, especially in the process of publishing online referrals so that they do not have to wait the next day to take referrals.

"BPJS" in facilitating services in hospitals, one of which is by giving authority in certain fields in decision-making for officers in hospitals, namely in the polyclinic service BPJS gives authority to the head of the polyclinic for approval of referral services. The head of the polyclinic who works in the morning shift becomes an obstacle in the approval of the referral letter for the afternoon polyclinic patient, therefore the patient is still waiting for the next day to get the referral letter approval.

The absence of notice boards about online referral procedures is also an obstacle based on observation, where patients still have to ask the clerk to make a referral. In addition, the wrong input of the referral hospital's destination from the first health facility becomes an obstacle because the patient must return to the first health facility to renew the referral.

"BPJS" services at PKU Muhammadiyah Karanganyar Hospital can only receive referrals from level 1 health facilities or fellow level 2 or type $\mathrm{C}$ health facilities, if there is an error in input at level 1 health facilities resulting in delayed service to patients, including the wrong input of polyclinic and Keith goals references from health facilities stored at level I health facilities.

\section{Supporting Factors for Online Referral}

The supporting factor description in this study is that inter-unit coordination is very helpful for services in the clinic stated by all reSOPndents. There is a coordinative attitude from the polyclinic registration officers, polyclinic nurses, and specialist doctors who assist in the service process. Coordination between units will have an impact on sub-optimal patient services, among others related to the changing doctor's schedule, inpatient registration flow from the clinic, registration flow information, and information about online referral patient flow .

A smooth internet network, as stated by respondents whose work area of PKU Muhammadiyah Karanganyar Hospital in urban areas is very helpful with the IndiHome network facility with unlimited packages with $10 \mathrm{Mbps}$ speed. The internet network helps especially in the implementation of the Hospital Management Information System (SIMRS) and the implementation of the "BPJS" vclaim, both systems can only work with the internet network.

Specialist doctor information as a referral hospital's destination is also useful for patients getting immediate treatment at the destination hospital. At PKU Muhammadiyah Karanganyar Hospital there are a number of specialist doctors who practice outside PKU Muhammadiyah Karanganyar Hospital, thus helping patients to get immediate outpatient or inpatient services at the destination hospital.

\section{Online Referral Implementation Policy}

The policy in implementing online referral is the Standard Operating Procedures (SOP) in PKU Muhammadiyah Karanganyar Hospital with document number 22.PO.06 dated 30 April 2016. According to respondents, the SOP regarding the referral is incomplete, so the 


\section{STRADA Jurnal Ilmiah Kesehatan}

DOI: $10.30994 /$ sjik.v9i1.323

ISSN: 2252-3847 (print); 2614-350X (online)

Vol.9 No.1. May 2020. Page.286-296

implementation in the field depends on jobdesk determined by the head of the unit. There is no monitoring and evaluation related to the online referral system . The incomplete online referral SOP is a problem in the field, having a direct impact on the service and education of officers to patients if there is a problem (Goniwala, 2017).

\section{CONCLUSION}

The preparation phase of the hospital's polyclinic officers has carried out a referral system with the issuance of SOP regarding references with Document number 22.PO.06, covering HR, doctor's schedule, referral health facilities, and infrastructure. The flow phase of online referral implementation is in accordance with Permenkes number 01 of 2012 concerning the referral system, which runs a tiered referral system from the first, second, and third levels. There are several obstacles or obstacles in the implementation of online referrals at PKU Muhammadiyah Karanganyar Hospital, namely the limited polyclinic officers and polyclinic registration, the absence of notice boards about the flow of making online referrals, giving authority by the BPJS to polyclinic officers only given to one person, disruption to the internet network and the vClaim program from "BPJS" in maintaining data or networks, and referral inputs that are not in accordance with the polyclinic objectives of a level 1 health facility and have not yet stored data in that level 1 health facility.

Supporting factors that help the smooth making of online referrals are smooth internet, good coordination between service units, and specialist information about online referral at the destination hospital. Policies in the form of Standard Operating Procedures (SOP) regarding referrals at PKU Muhammadiyah Karanganyar Hospital with document number 22.PO.06 dated 30 April 2016. The SOP is incomplete so that it is implemented based on the jobdesk given by the head of each unit.

\section{REFERENCE}

Creswell, J.W, (2013). Research Design Pendekatan Kualitatif, Kuantitatif, dan Mixed, edisi ketiga, Pustaka Pelajar, Yogyakarta.

Goniwala, G., 2017. Gambaran Pelaksanaan Rujukan Peserta BPJS Kesehatan di Puskesmas Tikala Baru dan Puskesmas Teling Atas di Kota Manado.

Hartini, Arso, . S. P. \& Sriatmi, A., (2016). Analisis Pelayanan Rujukan Pasien BPJS Di RSUD Chatib Quzwain Kabupaten Sarolangun Provinsi Jambi. Jurnal Kesehatan Masyarakat (e-Journal), 4(4).

Luti, I., Hasanbasri, M. \& Lazuardi, L., 2012.Kebijakan Pemerintah Daerah Dalam Meningkatkan Sistem Rujukan Kesehatan Daerah Kepulauan Di Kabupaten Lingga Provinsi Kepulauan Riau. Jurnal Kebijakan Kesehatan Indonesia, 01(01), pp. 24-35.

Manullang, (2008), Dasar-Dasar Manajemen, Yogyakarta: Ghalia Indonesia.

Moleong, L. J. (2010). Metodologi Penelitian Kualitatif, Bandung: Remaja Rosda Karya.

Notoatmodjo, S. (2012). Metodologi Penelitian Kesehatan. Jakarta: Rineka Cipta.

Peraturan Menteri Kesehatan No 01 Tahun 2012 Sistem Rujukan Pelayanan Kesehatan Perorangan. 18 Januari 2012. Jakarta.

Peraturan Menteri Kesehatan Republik Indonesia No. 340/MENKES/PER/III/2010 Klasifikasi Rumah Sakit. Jakarta. 11 Maret 2010. 


\section{STRADA Jurnal Ilmiah Kesehatan}

DOI: $10.30994 /$ sjik.v9i1.323

ISSN: 2252-3847 (print); 2614-350X (online)

Vol.9 No.1. May 2020. Page.286-296

Primasari, K. L., 2015. Analisis Sistem Rujukan Jaminan Kesehatan Nasional RSUD. Dr. Adjidarmo Kabupaten Lebak. Jurnal Administrasi Kebijakan Kesehatan, 1(2), pp.7886.

Ratnasari, Dwi. (2017). Analisis Pelaksanaan Sistem Rujukan Berjenjang Bagi Peserta JKN di Puskesmas X Kota Surabaya. JAKI. 5(2), 145-154

Undang-Undang No 24 Tahun 2011. Badan Penyelenggaraan Jaminan Sosial. 25 November 2011. Jakarta. 